Assiut University web-site: www.aun.edu.eg

\title{
DETECTION OF SUBCLINICAL MASTITIS IN A DAIRY FARM IN BENI-SUEF CITY, EGYPT
}

\author{
ADEL MUSTAFA EL-KHOLY; GAMAL MOHAMED HASSAN; MOHAMED MAAROUF \\ ALI ZEINHOM and MOHAMED ADEL AHMED MOHAMED EL-KLAWY \\ Food Hygiene Department, Faculty of Veterinary Medicine, Beni-Suef University, Egypt.
}

Received: 31 January 2018; Accepted: 4 April 2018

\begin{abstract}
A total of 116 quarter milk samples were collected aseptically from apparently healthy udders of 29 cows in a dairy farm in Beni-Suef city, Egypt; for detection of subclinical mastitis using California mastitis test (CMT), somatic cell count (SCC), chemical and microbiological examination. Thirteen cows (44.83\%) were subclinically mastitic with 27 mastitic quarters (23.28\%). The scores of CMT showed 11 quarters $(40.74 \%)$ as +1 and 16 quarters $\left(59.26 \%\right.$ ) as +2 . The SCC of fore left (FL) quarter milk samples was $4.3 \times 10^{5} \pm 1.2 \times 10^{5}$, while of fore right (FR) quarter milk samples was $3.8 \times 10^{5} \pm 1.1 \times 10^{5}$, but for SCC of hind left (HL) quarter milk samples was $2.4 \times 10^{5} \pm 9.5 \times 10^{4}$ and SCC of hind right (HR) quarter milk samples was $2.2 \times 10^{5} \pm 7.9 \times 10^{4}$. The isolated micro-organisms from the examined milk samples were Staphylococcus aureus, Coagulase negative Staphylococci (CNS), Streptococcus spp, E.coli and Aspergillus fumigatus. The present study assured that the indirect tests of subclinical mastitis are more suitable for selecting cows with intramammary infections for subsequent bacteriological sampling.
\end{abstract}

Key words: Subclinical mastitis, CMT, SCC.

\section{INTRODUCTION}

Among the animal diseases which affect the profitability of rearing animals, mastitis is considered to be one of the most expensive diseases in terms of production losses (Bardhan, 2013). Mastitis is a very devastating disease of dairy animals which influences the quality and quantity of milk (Akhtar et al., 2012). In case of mastitis, dairy industry suffers economic losses because of low quality milk that is not fit for human consumption, decrease in milk yield, premature culling of animals and replacements (Batavani et al., 2007).

Mastitis occurs throughout the world wherever dairy animals are found. Mastitis may be classified as clinical and subclinical. In contrast to visible changes in the acute form of mastitis, there is absence of gross abnormalities in the milk or udder in case of subclinical mastitis. Most of the mastitis is subclinical in nature and its prevention depends primarily on good management practices in dairy herd which includes stress-free environment, proper maintenance and operation of milking equipment, good milking procedures (Konwar et al., 2009).

Corresponding author: Dr. MOHAMED ADEL

E-mail address:m.adel39@yahoo.com

Present address: Food Hygiene Department, Faculty of Veterinary

Medicine, Beni-Suef University, Egypt.
Subclinical mastitis is an inflammation of the mammary gland without noticeable signs, although it is accompanied by $15-45 \%$ reduction in daily milk yield and altered milk composition (Swinkels et al., 2005; Halasa et al., 2007). Subclinical mastitis is of great economic importance to dairy farmers because it results in reduction in milk yield and undesirable changes in the milk's composition, as well as increased costs associated with control strategies (Halasa et al., 2009). Subclinical mastitis can be recognized indirectly by several diagnostic methods including the California mastitis test (CMT) and somatic cell count (SCC); These tests are preferred to be screening tests for subclinical mastitis as they can be used easily, yielding rapid as well as satisfied results (Joshi and Gokhale, 2006).

Over one hundred different microorganisms have been isolated from bovine mastitis, but the most frequently isolated microorganisms are Staphylococci, Streptococci and Gram-negative bacteria (Oliver et al., 2004; Hussain et al., 2012; Hussain et al., 2013). Staphylococci are the main etiological agents of mastitis in dairy cows (Unal and Yildirim, 2010). Although Staphylococcus aureus has been described as one of the most important mastitis pathogens in cattle, coagulasenegative Staphylococciare increasingly becoming recognized as etiologic agents associated with intramammary infections (IMI) in most countries (Unal et al., 2012). 
Seriousness of mycotic infection of mammary glands depends upon the species of the fungus involved as well as the percentage of infectivity (Tarfarosh and Purohit, 2008). Bovine mycotic mastitis is usually caused by yeasts, but mastitis due to filamentous fungi mostly Aspergillus fumigatus has been reported; it occurs as sporadic cases affecting a small percentage of cows or as outbreaks affecting the majority of animals (Abd El Razik et al., 2011). Fungal infections account for $2 \%-13 \%$ of all cases of mastitis in cows in Poland (Krukowski et al., 2000; Krukowski et al., 2006).

Otherwise, from public health view, the assessment of subclinical mastitis etiological pathogens aids to classify the healthy sound milk samples from those of public health hazard as the limits recommended by European countries standards (IDF, 1996) and Egyptian standards (Egyptian Standards, 2001). Therefore, the aim of this work is to detect the subclinical mastitis in a dairy farm in Beni-Suef city by using field tests, chemical examination, isolation and identification of different pathogens causing subclinical mastitis.

\section{MATERIALS AND METHODS}

\section{Collection of the samples:}

A total of 116 quarter milk samples were collected aseptically from apparently healthy udders of 29 cows in a dairy farm in Beni-Suef city according to the procedure recommended by Quinn et al. (2002). The samples were properly packed, stored in an ice box (at $4^{\circ} \mathrm{C}$ ) and transferred to the laboratory with a minimum of delay to be examined chemically and microbiologically.

\section{Preparation of the samples (APHA, 1992):}

Each sample was divided aseptically into 2 parts. The $1^{\text {st }}$ was transferred to the lab for chemical examination and numbering of the somatic cell count, while the $2^{\text {nd }}$ one was used for microbiological examination.

\section{Examination of the samples:}

\section{1- California mastitis test (CMT), (Saloniemi, 1995):}

A plastic vessel with 4 shallow wells was used for collecting approximately $2 \mathrm{ml}$ of milk from each udder quarter, then equal amount of alkali reagent (kerbl® reagent) was added. A gentle circular motion was applied to the mixtures in horizontal plane for 5 seconds and the different degrees of gel were recorded, according to the system used in the Nordic countries as the scoring is made from 1-5.

\section{2- Somatic cell count (SCC):}

All the milk samples were examined automatically for somatic cell count by using The Nucleo Counter ${ }^{\circledR}$ SCC-100 ${ }^{\mathrm{TM}}$. The sample was warmed in water bath at $35^{\circ} \mathrm{C}$ for 5 minutes, and then mixed automatically before reading (Radostitis et al., 2000).

\section{3- Chemical examination:}

All the milk samples were examined using Lactoscan milk analyzers (Ultrasonic portable milk analyzer, LSSP001, Bulgaria) for lactose, protein and fat $\%$.

\section{4- Microbiological examination:}

4-a) Cultivation of the samples (Sayed et al., 2011). All the milk samples were examined microbiologically by collecting $10 \mathrm{ml}$ of a well-mixed milk sample and added in a sterile plastic centrifugated tube, then centrifugated at 3000 r.p.m. for 20 minutes and the cream and supernatant fluids were discarded. A loopful from the sediment was taken and streaked onto the surface of Azide maltose agar for Streptococcus spp, Baired parker agar for Staphylococcus spp, MacConkey agar for Enterobacteriacae and Sabouraud dextrose agar with chloramfenicol (CMF) $500 \mathrm{mg}$ for yeasts and molds. The suspected organisms were cultured on nutrient and Sabouraud slope agars which incubated at $37^{\circ} \mathrm{C}$ for 24-48 hours as well as $25^{\circ} \mathrm{C}$ for 5-7days, respectively.

4-b) Identification of the isolated organisms was done according to APHA (1992); Koneman et al. (1992); Collee et al. (1996); Quinn et al. (2002) based on their Gram-reaction, colony growth and further confirmation.

\section{RESULTS}

Table 1: The prevalence of subclinical mastitis at udder-quarter level.

\begin{tabular}{|c|c|c|c|c|c|c|c|c|c|c|c|c|c|c|c|c|c|c|}
\hline \multirow{2}{*}{\multicolumn{2}{|c|}{$\begin{array}{l}\text { No. of the } \\
\text { infected } \\
\text { animals }\end{array}$}} & \multirow{2}{*}{$\begin{array}{l}\text { No. of the } \\
\text { examined } \\
\text { quarters }\end{array}$} & \multicolumn{4}{|c|}{ CMT } & \multicolumn{4}{|c|}{ SCC } & \multicolumn{4}{|c|}{$\begin{array}{c}\text { Bacteriological } \\
\text { result }\end{array}$} & \multicolumn{4}{|c|}{$\begin{array}{c}\text { Yeasts \& molds } \\
\text { Result }\end{array}$} \\
\hline & & & & sitive & $\mathrm{Ne}$ & gative & & sitive & $\mathrm{Ne}$ & gative & & ositive & Neg & ative & pos & itive & $\mathrm{Ne}$ & ative \\
\hline No. & $\%$ & \multirow{2}{*}{116} & No. & $\%$ & No. & $\%$ & No. & $\%$ & No. & $\%$ & No. & $\%$ & No. & $\%$ & No. & $\%$ & No. & $\%$ \\
\hline 13 & 44.83 & & 27 & 23.28 & 89 & 76.72 & 27 & 23.28 & 89 & 76.72 & 27 & 23.28 & 89 & 76.72 & 11 & 9.48 & 105 & 90.52 \\
\hline
\end{tabular}


Table 2: Statistical analytical results of CMT in the examined samples.

\begin{tabular}{|c|c|c|c|c|c|c|c|c|c|c|c|c|c|}
\hline \multirow{3}{*}{ 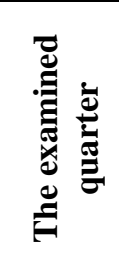 } & \multirow{3}{*}{ 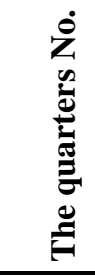 } & \multirow{2}{*}{\multicolumn{2}{|c|}{$\begin{array}{c}\text { Negative } \\
\text { CMT } \\
\text { samples }\end{array}$}} & \multirow{2}{*}{\multicolumn{2}{|c|}{$\begin{array}{c}\text { Positive } \\
\text { CMT } \\
\text { samples }\end{array}$}} & \multicolumn{8}{|c|}{ Positive CMT Samples } \\
\hline & & & & & & \multicolumn{2}{|c|}{$\begin{array}{c}\text { Score } \\
-\end{array}$} & \multicolumn{2}{|c|}{$\begin{array}{c}\text { Score } \\
+\end{array}$} & \multicolumn{2}{|c|}{$\begin{array}{c}\text { Score } \\
++\end{array}$} & \multicolumn{2}{|c|}{$\begin{array}{c}\text { Score } \\
+++\end{array}$} \\
\hline & & No. & $\%$ & No. & $\%$ & No. & $\%$ & No. & $\%$ & No. & $\%$ & No. & $\%$ \\
\hline FL & 29 & 20 & 68.97 & 9 & 31.03 & $\mathbf{0}$ & 0.00 & 2 & 22.22 & 7 & 77.78 & $\mathbf{0}$ & 0.00 \\
\hline FR & 29 & 20 & 68.97 & 9 & 31.03 & $\mathbf{0}$ & 0.00 & 4 & 44.44 & 5 & 55.56 & $\mathbf{0}$ & 0.00 \\
\hline HL & 29 & 24 & 82.76 & 5 & 17.24 & $\mathbf{0}$ & 0.00 & 3 & 60 & 2 & 40 & $\mathbf{0}$ & 0.00 \\
\hline HR & 29 & 25 & 86.21 & 4 & 13.79 & $\mathbf{0}$ & $\mathbf{0 . 0 0}$ & 2 & 50 & 2 & 50 & $\mathbf{0}$ & 0.00 \\
\hline Total & 116 & 89 & 76.72 & 27 & 23.28 & $\mathbf{0}$ & 0.00 & 11 & 40.74 & 16 & 59.26 & 0 & 0.00 \\
\hline
\end{tabular}

$\mathrm{FL}=$ foreleft, $\mathrm{FR}=$ foreright, $\mathrm{HL}=$ hindleft, $\mathrm{HR}=$ hindright.

Table 3: Frequency percentages of single and mixed infection in the quarter milk cow's samples.

\begin{tabular}{|c|c|c|c|c|c|c|c|c|}
\hline \multirow{3}{*}{ The examined quarter } & \multirow{2}{*}{\multicolumn{2}{|c|}{$\begin{array}{l}\text { Single } \\
\text { infection }\end{array}$}} & \multicolumn{6}{|c|}{ Mixed infection } \\
\hline & & & & \multirow{2}{*}{$\begin{array}{c}\begin{array}{r}\text { Double } \\
\text { infection }\end{array} \\
\%\end{array}$} & \multirow{2}{*}{\multicolumn{2}{|c|}{$\begin{array}{lc} & \begin{array}{r}\text { Triple } \\
\text { infection }\end{array} \\
\text { No. } & \%\end{array}$}} & \multicolumn{2}{|r|}{ Tetra infection } \\
\hline & No. & $\%$ & No. & & & & No. & $\%$ \\
\hline FL & 2 & 7.41 & 4 & 14.81 & 3 & 11.11 & $\mathbf{0}$ & 0.00 \\
\hline FR & 2 & 7.41 & 4 & 14.81 & 2 & 7.41 & 1 & 3.70 \\
\hline HL & 5 & 18.52 & $\mathbf{0}$ & 0.00 & $\mathbf{0}$ & 0.00 & $\mathbf{0}$ & 0.00 \\
\hline HR & 3 & 11.11 & 1 & 3.70 & $\mathbf{0}$ & 0.00 & $\mathbf{0}$ & 0.00 \\
\hline \multirow{2}{*}{ Total } & \multirow{2}{*}{\multicolumn{2}{|c|}{$12(44.44 \%)$}} & 9 & 33.33 & 5 & 18.52 & 1 & 3.70 \\
\hline & & & \multicolumn{6}{|c|}{$15(55.56 \%)$} \\
\hline
\end{tabular}

$\mathrm{FL}=$ foreleft, $\mathrm{FR}=$ foreright, $\mathrm{HL}=$ hindleft, $\mathrm{HR}=$ hindright.

Table 4: Incidence of the identified microorganisms in relation to the total isolates (49).

\begin{tabular}{cccc}
\hline \multirow{2}{*}{ Type of the isolated microorganisms } & \multicolumn{2}{c}{ Number of isolates } & \multirow{2}{*}{ Type of infection } \\
\cline { 2 - 4 } & No. & $\%$ & Single and mixed \\
\hline Staphylococcus aureus & 7 & 14.28 & Single and mixed \\
\hline Coagulase negative Staphylococci $($ CNS $)$ & 6 & 12.24 & Mixed \\
\hline Streptococcus Spp. & 5 & 10.2 & Single and mixed \\
\hline E. coli & 20 & 40.82 & Mixed
\end{tabular}

Table 5: Statistical analytical results of $\mathrm{SCC} / \mathrm{ml}$ of the examined samples.

\begin{tabular}{cccccccccc}
\hline \multirow{2}{*}{$\begin{array}{c}\text { The examined } \\
\text { quarter }\end{array}$} & \multicolumn{4}{c}{ Normal } & \multicolumn{4}{c}{ Subclinical mastitis } & Mean \pm S.E.M. \\
\cline { 2 - 8 } & No. & $\%$ & Min. & Max. & No. & $\%$ & Min. & Max. & \\
\hline FL & 20 & 68.97 & $1 \times 10^{4}$ & $3.2 \times 10^{5}$ & 9 & 31.03 & $3.8 \times 10^{5}$ & $2 \times 10^{6}$ & $4.3 \times 10^{5} \pm 1.2 \times 10^{5}$ \\
\hline FR & 20 & 68.97 & $1 \times 10^{4}$ & $2.9 \times 10^{5}$ & 9 & 31.03 & $4 \times 10^{5}$ & $2 \times 10^{6}$ & $3.8 \times 10^{5} \pm 1.1 \times 10^{5}$ \\
\hline HL & 24 & 82.76 & $1 \times 10^{4}$ & $2.5 \times 10^{5}$ & 5 & 17.24 & $3.8 \times 10^{5}$ & $2 \times 10^{6}$ & $2.4 \times 10^{5} \pm 9.5 \times 10^{4}$ \\
\hline HR & 25 & 86.21 & $1 \times 10^{4}$ & $3.5 \times 10^{5}$ & 4 & 13.79 & $4 \times 10^{5}$ & $2 \times 10^{6}$ & $2.2 \times 10^{5} \pm 7.9 \times 10^{4}$ \\
\hline
\end{tabular}

$\mathrm{FL}=$ fore left, $\mathrm{FR}=$ fore right, $\mathrm{HL}=$ hind left, $\mathrm{HR}=$ hind right, Min. = minimum, Max. =maximum 
Table 6: Frequency distribution of $\mathrm{SCC} / \mathrm{ml}$ of the examined samples.

\begin{tabular}{|c|c|c|c|c|c|c|c|c|c|}
\hline \multirow{3}{*}{ The quarter state } & \multirow{3}{*}{ Intervals } & \multicolumn{8}{|c|}{ The examined quarter } \\
\hline & & \multicolumn{2}{|c|}{ FL } & \multicolumn{2}{|c|}{ FR } & \multicolumn{2}{|c|}{ HL } & \multicolumn{2}{|c|}{ HR } \\
\hline & & No. & $\%$ & No. & $\%$ & No. & $\%$ & No. & $\%$ \\
\hline Normal & $1 \times 10^{4}-<3.5 \times 10^{5}$ & 20 & 68.96 & 20 & 68.96 & 24 & 82.76 & 25 & 86.20 \\
\hline \multirow{6}{*}{$\begin{array}{l}\text { Subclinical } \\
\text { mastitis }\end{array}$} & $3.5 \times 10^{5}-<6.9 \times 10^{5}$ & 2 & 6.90 & 4 & 13.79 & 3 & 10.34 & 2 & 6.90 \\
\hline & $6.9 \times 10^{5}-<1 \times 10^{6}$ & 1 & 3.45 & $\mathbf{0}$ & 0.00 & $\mathbf{0}$ & 0.00 & $\mathbf{0}$ & 0.00 \\
\hline & $1 \times 10^{6}-<1.3 \times 10^{6}$ & 1 & 3.45 & 1 & 3.45 & 0 & 0.00 & 1 & 3.45 \\
\hline & $1.3 \times 10^{6}-<1.7 \times 10^{6}$ & 2 & 6.90 & 2 & 6.90 & $\mathbf{0}$ & 0.00 & $\mathbf{0}$ & 0.00 \\
\hline & $1.7 \times 10^{6}-\leq 2 \times 10^{6}$ & 3 & 10.34 & 2 & 6.90 & 2 & 6.90 & 1 & 3.45 \\
\hline & Total & 29 & 100 & 29 & 100 & 29 & 100 & 29 & 100 \\
\hline
\end{tabular}

$\mathrm{FL}=$ foreleft, $\mathrm{FR}=$ foreright, $\mathrm{HL}=$ hindleft, $\mathrm{HR}=$ hindright.

Table 7: Correlation between the positive CMT and the microbiological results of the examined samples.

\begin{tabular}{|c|c|c|c|c|c|c|c|}
\hline \multirow{2}{*}{$\begin{array}{l}\text { CMT } \\
\text { score }\end{array}$} & \multirow{2}{*}{$\begin{array}{l}\text { No. of the } \\
\text { samples }\end{array}$} & \multicolumn{2}{|c|}{ Bacteriological result } & \multirow{2}{*}{$\begin{array}{c}\text { Agreement } \\
\%\end{array}$} & \multicolumn{2}{|c|}{$\begin{array}{c}\text { Yeasts \& molds } \\
\text { result }\end{array}$} & \multirow{2}{*}{ Agreement \% } \\
\hline & & $+v e$ & -ve & & $+v e$ & -ve & \\
\hline- & 89 & 0 & 89 & - & $\mathbf{0}$ & 89 & - \\
\hline+ & 11 & 11 & $\mathbf{0}$ & 100 & 4 & 7 & 36.36 \\
\hline++ & 16 & 16 & $\mathbf{0}$ & 100 & 7 & 9 & 43.75 \\
\hline+++ & 0 & 0 & 0 & - & 0 & 0 & - \\
\hline
\end{tabular}

Table 8: Compositional changes in the milk constituents associated with elevated SCC.

\begin{tabular}{cccccccc}
\hline & \multirow{2}{*}{$\begin{array}{c}\text { Average of normal } \\
\text { milk according to } \\
\text { NMC (1987) }\end{array}$} & \multicolumn{5}{c}{$\begin{array}{c}\text { Average of milk constituents with high } \\
\text { SCC (\%) }\end{array}$} \\
\cline { 3 - 7 } SNF & FL & FR & HL & HR \\
\hline Fat & 8.9 & 8.5 & 8 & 9 & 8.9 \\
\hline Lactose & 3.5 & 2.8 & 2.8 & 3.2 & 4.3 \\
\hline Total protein & 4.9 & 4.7 & 4.8 & 5.1 & 4.9 \\
\hline
\end{tabular}

\section{DISCUSSION}

CMT principle is based upon the amount of cellular nuclear protein present in the milk sample, thus correlated to SCC (Greiner et al., 2000).

The results listed in Table (1) showed that $13(44.83 \%)$ ) cows of the total examined 29 dairy cows had subclinical mastitis and consequently, the 116 examined cows' quarter milk samples classified into $89(76.72 \%)$ CMT negative and 27(23.28\%) CMT positive samples.

The summarized data of SCC as compared with bacteriological examination showed a positive correlation between SCC and bacteriological status in the examined quarter milk samples (Table 1). These results were similar to Fox et al. (1985). Some observations in this study were different in results than other studies which may be attributed to the prevention and control programs, sampling, methods of isolation, type of management employed and other factors. The right management leads to a reduction of mastitis and vice versa. Also, the most infectious diseases, mastitis risk factors depend on three components: exposure to udder pathogens, cow defense mechanisms, environmental and management factors (Suriyasathaporn et al., 2000).

The obtained results in Table (2) showed that among the CMT positive samples, the highest incidence was recorded in CMT $(+2)$ as $59.26 \%$, while none of the positive CMT showed score +3 .

It was clear from the obtained results that CMT used as indicator and screening of bovine mastitis and 
microbiological status of milk. The CMT has the advantages of being animal - side, inexpensive and rapid to be performed (Contreras et al., 1996). From the other side, this test may give positive result as in case of very early (colostrum), late lactation, teat end injury, fluctuating and irregular milking vacuum and abnormal health of cow such as foot rot and uterine infection, one to two weeks following treatment and with non-infected quarters (Robert and Edmondson, 1993; Abdurahman, 2006). So, it should carry out with other tests as SCC and microbiological examination to detect the cause or products of mastitis.

As shown in Table (3) the incidences of single and mixed infection were $44.44 \%$ and $55.56 \%$ in the positive cows' milk samples for subclinical mastitis, respectively. These findings reflect an idea about the level of environmental microbial contamination (Sayed and Abdel-Hafeez, 2009). In addition, Staphaureus may predispose the animals to infection by coliforms or other pathogens (Ibtisam et al., 1993). On the other hand, Srinivasan et al. (2013) reported that single quarter infection was more common compared to mixed quarter infection, but the incidences of mixed and single infection were $80.77 \%$ and $19.23 \%$ in positive cows' milk samples for subclinical mastitis as obtained by Sayed et al. (2011).

Inspection of Table (4) revealed that the main isolated organisms from the examined milk samples were Staphylococcus aureus, CNS, Streptococcus spp, E.coli and Aspergillus fumigatus in a percentage of $14.28,12.24,10.2,40.82$ and $22.45 \%$, respectively. The obtained data were in agreement with that reported by Kassa et al. (2014); Alekish, (2015); ElBagory and Zayda (2015). The problem of these microorganisms not only economic or disturb animal health but also, produce a public health hazard to human being.

Although results of some screening tests often show good correlation with the bacteriological findings, yet no single test was completely satisfactory for detection of subclinical mastitis (EL-Kholy et al., 1994). The most important factor affecting the SCC of the milk from an individual quarter depends upon the infection status of the quarter (Dohoo and Meek, 1982).

The listed results in Table (5) declared that all the cows positive CMT had $\mathrm{SCC} \geq 200.000$ cells $/ \mathrm{ml}$ so, all these cows defined as having subclinical mastitis (Haltia et al., 2006; Moroni et al., 2006).

The results of CMT as compared with bacteriological, yeasts and molds examination were recorded in Table (7) from which it was evident that 89 out of the 116 quarters cow's milk samples showed (-) CMT score, negative bacteriological and negative yeasts and molds examination; and in compatable, all the isolated microorganisms were from the positive CMT samples.

\section{CONCLUSION}

SCC, CMT and intramammary infection are associated significantly; therefore, these parameters provide good information to evaluate udder health status in cows.

\section{REFERENCES}

Abd El Razik, K.H.A.; Khaled, A.; Abdelrahman, Sherein, Abd El-Moez, Enas and Danial, N. (2011): New approach in diagnosis and treatment of bovine mycotic mastitis in Egypt. Afr. J. Microbial. Res. 5 (31): 5725-5732.

Abdurahman, O.A.S. (2006): Udder health and milk quality among camels in the Errer valley of eastern Ethiopia. Livestock Res. Rural Development, 18(8): 3-11.

Akhtar, A.; Umer, K.B.; Tanweer, A.J. and Habibullah. (2012): Prevalence of mastitis and identification of causative pathogens in local and crossbred cows in Dera Ismail Khan. Pak. J. Sci, 64: 265-268.

Alekish, M.O. (2015): The association between the somatic cell count and isolated microorganisms during subclinical mastitis in heifers in Jordan. Faculty of Veterinary Medicine, Jordan University of Science and Technology, Irbid, Jordan.Vet. Med. 60 (2): 71-76.

APHA (American Public Health association) (1992): Standard method for the examination of dairy products. $16^{\text {th }}$ Ed., New York.

Bardhan, D. (2013): Estimates of economic losses due to clinical mastitis in organized dairy farms. Indian J. Dairy Sci, 66(2): 168-172.

Batavani, R.A.; Asri, S. and Naebzadeh, H. (2007): The effect of subclinical mastitis on milk composition in dairy cows. Iran. J. Vet. Res., University of Shiraz,8 (3): ser. 20: 205-211.

Contreras, A.; Sierra, D.; Corrales, J.C.; Sanchez, A. and Marco, J. (1996): Physiological threshold of somatic cell count and California mastitis test for diagnosis of caprine subclinical mastitis. Small Rumin. Res, 21: 259-264.

Collee, J.G.; Miles, R.S. and Wan, B. (1996): Tests for identification of bacteria. In Mackie and mac Cartney' s Practical Medical Microbiology, 14 the edn, app.131-150. Edited by collee, J.G.; Fraser A.G.; Marimon, B.P. and Simmons, a New York: Churchill Livingstone.

Dohoo, I.R. and Meek, A.H. (1982): Somatic cell count in bovine milk. Can. Vet. J. 23(4): 119125. 
Egyptian Standards (2001): Raw milk. Egyptian organization for standardization and quality control, No.154.

El-Bagory, A.M. and Zayda, M.G. (2015): Impact of Subclinical Mastitis on Cow's and Buffalo's Milk Quality. 2nd Conference of Food Safety, Suez Canal University. Fac. Vet. Med. 1: 67-75.

EL-Kholy, A.M.; Sein, H.I. and Thabet, A.EL.R. (1994): Chemical and cytobacteriological studies for detection of subclinical mastitis. Assiut Vet. Med. J. 30(60): 154-164.

Fox, L.K.; Shook, G.E. and Schultz, L.H. (1985): Factors related to milk loss in quarters with low somatic cell count. J. Dairy Sci. 68:21002107.

Greiner, M.; Pfeiffer, D. and Smith, R.D. (2000): Principles and practical application of the receiver-operating characteristics analysis for diagnostic tests. Prev. Vet. Med. 45: 23-41.

Halasa, T.; Huijps, K.; Osteras, O. and Hogeveen, $H$. (2007): Economic effects of bovine mastitis and mastitis management. Vet. Quarterly.29: 18-31.

Halasa, T.; Nielen, M. and De Roos, A. (2009): Production loss due to new subclinical mastitis in Dutch dairy cows estimated with a test-day model. J. Dairy Sci. 92: 599-606.

Haltia, L.; Honkanen-Buzalski, T.; Spiridonova, I.; Olkonen, A. and Myllys, V. (2006): A study of bovine mastitis, milking procedures and management practices on 25 Estonian dairy herds. Acta. Vet. Scand. 48 (1): 22.

Hussain, R.; Javed, M.T.; Khan, A.; Mahmood, F. and Kausar, R. (2012): Mastitis and associated histo-pathological consequences in the context of udder morphology. Int. J. Agric. Biol.14: 947-952.

Hussain, R.; Khan, A.; Javed, M.T. and Ali, F. (2013): Morphometric and pathological studies on mammary gland of slaughtered Nili-Ravi buffaloes. Pak. J. Agric. Sci. 50: 123-130.

Ibtisam, E.; Mohamed, G.E.; Mohamed, G.E. and ElOwni, O.A.O. (1993): A study on the incidence and etiology of bovine mastitis in Sudan. 2nd Sci. Cong. Egyptian Society for Cattle Diseases, Assiut, Egypt. 326-332.

IDF (International Dairy Federation) (1996): Bacteriological quality of raw milk. 41 Square Vevgote, 13-1030, Brussels, Belgium.

Joshi, S. and Gokhale, S. (2006): Status of mastitis as an emerging disease in improved and periurban dairy farms in India. Ann. New York Acad. Sci. 1081: 74-83.

Kassa, F.; Ayano, A.A.; Abera, M. and Kiros, A. (2014): Longitudinal study of bovine mastitis in Hawassa and Wendo Genet small holder dairy. G.J.S.F.R. 14 (2).
Koneman, E.W.; Allen, S.D.; Janda, W.M.; Schreckenberger, P.C. and Winn, W.C. (1992): Packaged in kit identification system. Color atlas and textbook of diagnostic microbiology. Koneman, E.W. (Eds.), $4^{\text {th }}$ Ed., B. Lippincott Co., Phliladelphia, PA., pp: 163170.

Konwar, D.; Barman, K. and Singh, Y. (2009): Management, A key to prevention of mastitis. Indian Dairyman. 61: 29-33.

Krukowski, H.; Lisowski, A.; Rozanski, P. and Skorka, A. (2006): Yeast and Algae isolated from cows with mastitis in the south-eastern part of Poland. Pol. J. Vet. Sci. 9: 181-184.

Krukowski, H.; Tietze, M.; Majewski, T. and Rozanski, P. (2000): Survey of yeast mastitis in dairy herds of small-type farms in the Lublin region, Poland, Mycopathologia. 150: 5-7.

Moroni, P.; Sgoifo Rossi.; Pissoni, G.; Bronzo, V.; Castiglioni, B. and Boettcher, P.J. (2006): Relationships between somatic cell count and intramammary infection in buffaloes. J. Dairy Sci. 89(3): 998-1003.

NMC (National Mastitis Council) (1987): Current concepts of bovine mastitis. $3^{\text {rd }}$ Ed., Arlington, VA. The Netherland.

Oliver, S.; González, R.; Hogan, J.; Jayarao, B. and Owens, W. (2004): Microbiological procedures for the diagnosis of bovine udder infection and determination of milk quality, $4^{\text {th }}$ Ed, National Mastitis Council, Verona, WI, USA: 1-28.

Quinn, P.j.; Markey, B.K.; Carter, M.E.; Donnelly, W.J.C.; Leonard, F.C. and Maguire. (2002): Veterinary microbiology and microbial diseases.1st Blackwell Science $1^{\text {st }} \mathrm{ed}$.

Radostitis, O.M.; Gay, C.C.; Blood, D.C. and Hinchcliff, K.W. (2000): Inveterinary medicine, a textbook of diseases of cattle, sheep, pigs, goats and horses, $9^{\text {th }}$ ed. W. B. Saunders, London, 603-660.

Robert, T.M. and Edmondson, J.E. (1993): Using the California mastitis test University of Missouri Extension.

Saloniemi, H. (1995): Use of somatic cell count in udder health work. In: Sandholm, M., Honkanen-Buzalski, T., Kaartinen, L. and Pyorala, S. (ed.) (University of Helsinki, Faculty of Veterinary Medicine), the Bovine Udder and Mastitis, 105-110. Gummerus Kirjapaino, Jyväskylä. (ISBN 951-834-047-1).

Sayed, S.M.; Mansy, M.F. and EL-Berbawy, S.M. (2011): Bacteriological studies on sub-clinical mastitis in cows and buffaloes with trails for its treatment. Assiut Vet. Med. J. 57(129).

Sayed, S.M. and Abdel-Hafeez, M.M. (2009): Bacteriological studies on pathogens causing subclinical mastitis in Holstein-Friesian dairy 
cows in Assiut Governorate. Assiut Vet. Med. J. 55(120): 46-58.

Srinivasan, P.; Jagadeswaran, D.; Manoharan, R.; Giri, T.; Balasubramaniam, G.A. and Balachandran, $P$. (2013): Prevalence and etiology of subclinical mastitis among buffaloes (Bubalusbubalus) in Namakkal, India. Pak. J. Biol. Sci., 16(23): 1776-1780.

Suriyasathaporn, W.; Schukken, Y.H.; Nielen, M. and Brands, A. (2000): Low somatic cell count: a risk factor for subsequent clinical mastitis in dairy herds. J. Dairy Sci., 83: 1248-1255.

Swinkels, J.M.; Hogeveen, H. and Zadoks, R.N. (2005): A partial budget model to estimate economic benefits of lactational treatment of subclinical Staphylococcus aureus mastitis. J. Dairy Sci. 88(12): 4273-4287.
Tarfarosh, M.A. and Purohit, S.K. (2008): Isolation of Candida spp. From mastitic cows and milkers. Vet. Scan. 3: 14-18.

Unal, N.; Askar, S.; Macun, H.C.; Sakarya, F.; Altun, B. and Yildirim, M. (2012): Panton-Valentine leukocidin and some exotoxins of Staphylococcus aureus and antimicrobial susceptibility profiles of Staphylococci isolated from milk of small ruminants. Trop. Anim. Health Prod.,44: 573-579.

Unal, N. and Yildirim, M. (2010): Antibiotic resistance profiles of Staphylococci species isolated from milk, teat skins and noses mucous of cows. Kafkas Univ. Vet. Fak. Derg. 16: 389-396.

\section{الكثف عن إلتهاب الضرع الخفي في مزرعة حلاب ببني سويف، مصر \\ عادل مصطفي الخولي ، جمال محمد حسن ، محمد معروف علي زينهم ، محمد عادل القلاوي}

E-mail: m.adel39@yahoo.com Assiut University web-site: www.aun.edu.eg

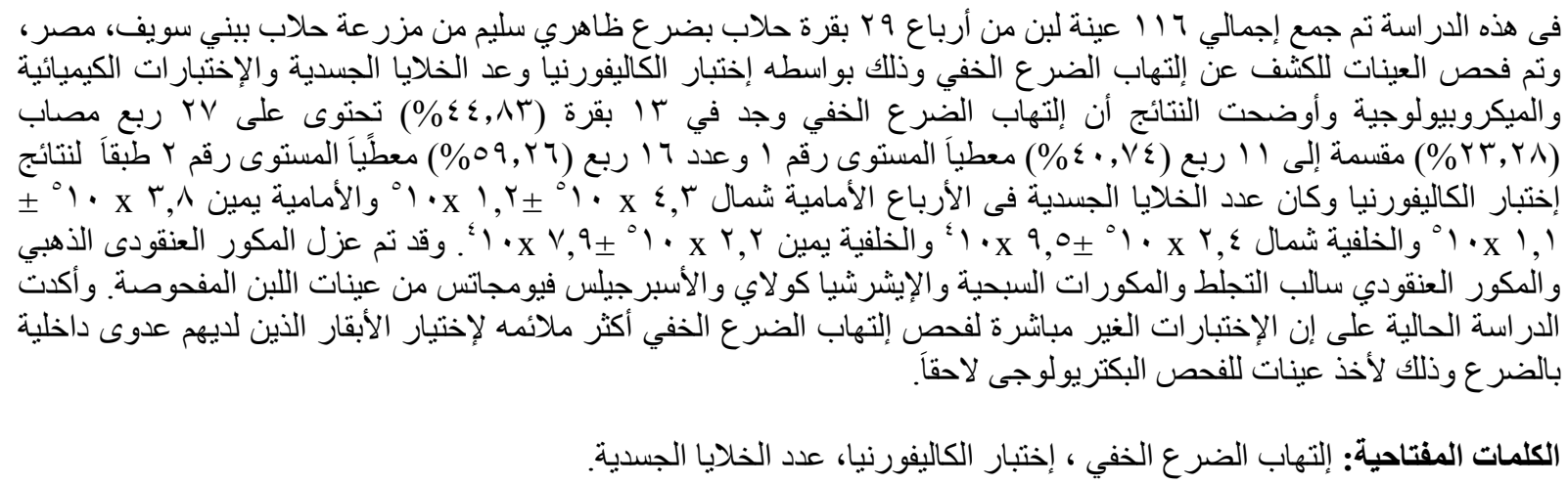

